Research Article

\title{
TRIAL OF PARTIAL SUBSTITUTION OF MAIZE (ZEA MAYS) BY PARKIA BIGLOBOSA PULP IN THE DIET OF JAPANESE QUAIL (COTURNIX JAPONICA)
}

\author{
${ }^{1}$ Atoguignima DADJO, ${ }^{2}$ Mamatchi MELILA, ${ }^{1}$ Essosimna Abalo KULO \\ ${ }^{1}$ Higher School of Agronomy (ESA), University of Lomé, 01 B.P. 1515, Lomé 01, Togo \\ ${ }^{2}$ Faculty of Sciences (FDS), University of Lomé, 01 B.P. 1515, Lomé 01, Togo
}

Article History: Received $18^{\text {th }}$ May 2021; Accepted $9^{\text {th }}$ June 2021; Published 25 ${ }^{\text {th }}$ August 2021

\begin{abstract}
Poultry farming has always been a means of combating malnutrition. In recent years, quails farming has offered us new choices of taste, with meat production to meet the increased demand in animal proteins. However, the big problem in the poultry sector remains the cost of food. To overcome this problem, the use of agricultural by-products in animal feeding remains capital. These by-products are readily available and rich in nutrients, as it is the case with Adansonia digitata and Parkia biglobosa pulp. This is the context in which this study is taking place, which is a contribution to the valorization of $P$. biglobosa pulp as a partial replacement for corn in quail nutrition as a source of energy and nutrients. A total of 540 curds was selected with an average body weight of $7.00 \pm 0.02 \mathrm{~g}$ and one day of age. Four batches of treatments were constituted, namely, batch control, batch $5 \%$, batch $10 \%$ and batch $15 \%$ according to the rates of substitution of corn by $P$. biglobosa pulp in their feed. The weekly weighings of the birds made it possible to follow their weight growth and the average weekly gain of the birds. The consumption index was thus determined on the basis of food consumption. The results showed that the substitution of maize by $P$. biglobosa pulp improved the weight and the average daily gain of the birds in the growth phase. Feed consumption and feed conversion ratio were low for the control batch compared to the treated batches during both rearing phases. Food consumption and the consumption index were more in favor of the control especially in the start-up phase compared to the treated batches. The pulp of $P$. biglobosa, by virtue of its nutritional quality, can therefore be used in quail feed at corn substitution rates of 5 to $15 \%$ without adversely affecting its zootechnical performance.
\end{abstract}

Keywords: Parkia biglobosa pulp, Coturnix japonica, Food conversion, Zootechnical performances.

\section{INTRODUCTION}

In Togo, agriculture is a key sector in the national strategy for economic development and the fighting against poverty. Indeed, since the end of colonization, development programs have assigned it the role of ensuring first and foremost food self-sufficiency, then, later, that of guaranteeing food security, a pledge of real sustainable development. The contribution of the livestock sub-sector is estimated at $6.73 \%$ to the national Gross Domestic Product (GDP) and 14\% to the Gross Agricultural Domestic Product (PIBA) which represents $40 \%$ of the GDP (MAEP, 2008). Short-cycle farming, especially poultry farming, has always been an effective way to fight hunger and malnutrition. In recent years, quail farming, or coturniculture, has attracted attention from specialists as a new avenue for diversifying poultry farming, offering consumers new taste choices and boosting meat production to meet the growing demand for animal protein (Ukashatu et al., 2014). Quail meat is renowned for its low caloric value and for its high quality protein and high biological value (Haruna et al., 1997). These qualities, especially the low fat content, are likely to distract consumers, especially those prone to hypertension, from the consumption of quail meat (Odo \& Nnadi, 2013). The quail is indeed a small rustic bird, early, very prolific and less demanding in space as in food consumption compared to other poultry. 
Developing coturniculture in Togo will then contribute to the fight against poverty through the creation of incomegenerating activities, eliminate hunger and malnutrition through the production of quality meat and eggs for the population. However, the major obstacle facing the poultry sector remains the cost of feed, which represents nearly $60 \%$ of the total expenses of poultry farms as for any other type of farming (Shamna et al. 2013). For a long time, and because of their high energy and protein content, corn-soy diets have been considered as staple feeds for poultry regardless of the type of production (egg, meat). Maize (Zea mays) forms the basis of most livestock feeds and is particularly popular with poultry, rabbits and pigs (Durunna et al., 2000). The grains are very useful as food for humans and animals as well as raw materials for industries. The high cost of cereals and the uncertainty of their sustainable supply as an energy source for livestock and poultry require the search for alternative and perhaps cheaper options (Agiang et al., 2004). So, develop alternative animal feeding systems based on agricultural by-products, such as
A. digitata and Parkia biglobosa pulps, which are known to be rich in carbohydrates, mineral and vitamin complexes. It can be a source of solution for the reduction of feed costs in poultry farming in general and coturniculture in particular. This will make quail farming even more favorable to all pockets as an income generating activity. This study aims to promote the breeding of animals based on local nonconventional ingredients, in the interest of increasing productivity per unit of available basic resources. It is in this context that, this study aims to contribute to the valorization of $P$. biglobosa pulp as a partial replacement of corn in quail feed as a source of energy and nutrients.

\section{MATERIAL AND METHODS}

\section{Animal material}

Day-old quail, from mature quail eggs (Plate 1), were selected on the basis of an average live weight of $7.00 \pm$ $0.02 \mathrm{~g}$.

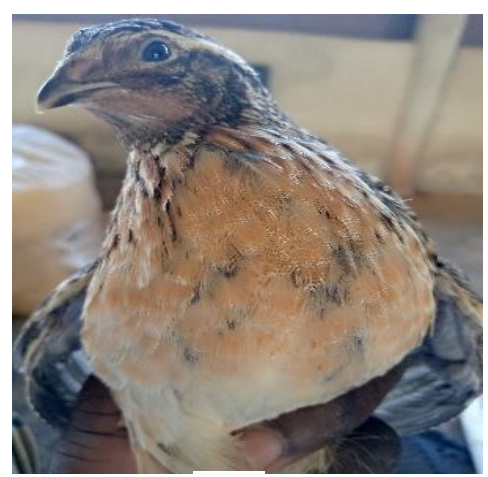

a

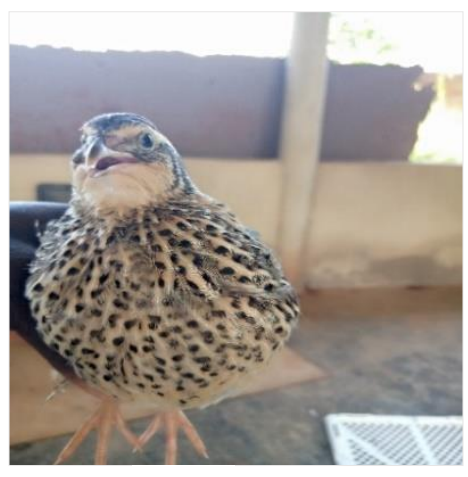

b

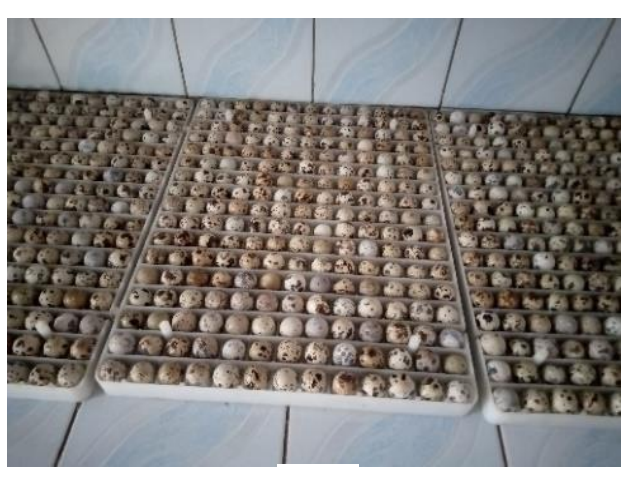

Plate 1. Photos of male quail (a); female quail (b) and quail eggs (c).

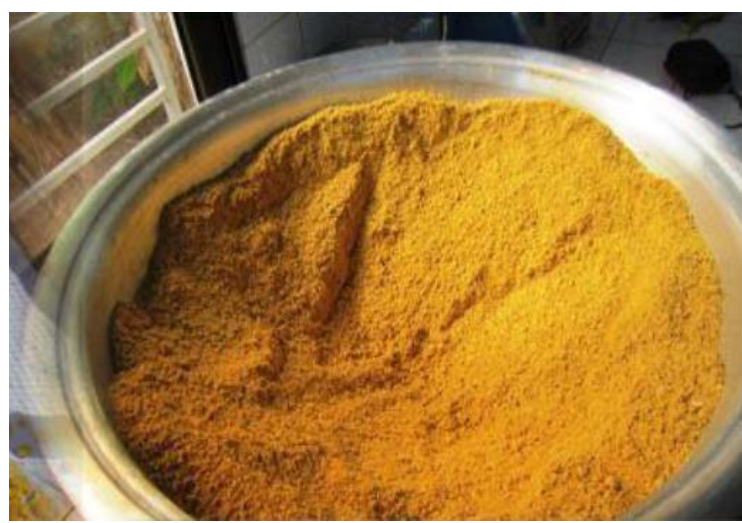

Photo 1. Parkia biglobosa pulp meal. 


\section{Methodology}

The bromatological profile of the P. biglobosa pulp was obtained by the AOAC method (Official Methods of Analysis).

\section{Ingredients used}

The ingredients used for the food formulation consisted of corn, soy, bran cubed to which we added the $P$ biglobosa pulp (Photo 1).

\section{Experimental design}

A total of 540 day-old quails were divided into four treatments, namely Control, T 5\%, T $10 \%$ and T 15\%. They were fed feeds with $0 \%, 5 \%, 10 \%$ and $15 \%$ corn substitution rate by $P$. biglobosa pulp respectively. The quail were randomly assigned to four treatment batches. Within each treatment batch, we have three replicates of 45 quail per replicate.

\section{Feed formulation of the animals}

The control batch feed was formulated according to the nutritional requirements of Japanese quail. From this control batch feed, we made a substitution of corn by cowpea pulp without considering the energy imbalance between the two ingredients, as shown in table 1.

Table 1. Feeding formulas for start-up and growth phases.

\begin{tabular}{|c|c|c|c|c|c|c|c|c|}
\hline \multirow[t]{2}{*}{ Ingredients } & \multicolumn{4}{|c|}{ Start-up } & \multicolumn{4}{|c|}{ Growth } \\
\hline & Control & $\mathrm{T} 5 \%$ & $\mathrm{~T} 10 \%$ & T $15 \%$ & Control & $\mathrm{T} 5 \%$ & $\mathrm{~T} 10 \%$ & T $15 \%$ \\
\hline Parkia biglobosa pulp & 0 & 5 & 10 & 15 & 0 & 5 & 10 & 15 \\
\hline White corn & 50 & 45 & 40 & 35 & 65 & 60 & 55 & 50 \\
\hline Wheat bran & 3 & 3 & 3 & 3 & 6 & 6 & 6 & 6 \\
\hline Soya seed cake & 22 & 22 & 22 & 22 & 4 & 4 & 4 & 4 \\
\hline Roasted soya seed & 10 & 10 & 10 & 10 & 12 & 12 & 12 & 12 \\
\hline Fish meal & 6.5 & 6.5 & 6.5 & 6.5 & 5.5 & 5.5 & 5.5 & 5.5 \\
\hline Flesh concentrate & 6 & 6 & 6 & 6 & 5 & 5 & 5 & 5 \\
\hline Oyster shell & 2 & 2 & 2 & 2 & 2 & 2 & 2 & 2 \\
\hline Premix flesh & 0.25 & 0.25 & 0.25 & 0.25 & 0.25 & 0.25 & 0.25 & 0.25 \\
\hline Méthionine & 0.1 & 0.1 & 0.1 & 0.1 & 0.1 & 0.1 & 0.1 & 0.1 \\
\hline Lysine & 0.15 & 0.15 & 0.15 & 0.15 & 0.15 & 0.15 & 0.15 & 0.15 \\
\hline Total (Kg) & 100 & 100 & 100 & 100 & 100 & 100 & 100 & 100 \\
\hline Metabolizable energy (kcal/ kg) & 2913.6 & 2750.3 & 2587 & 2423.6 & 3041.9 & 2878.5 & 2715.2 & 22251.9 \\
\hline Crude protein $(\%)$ & 25.109 & 24.91 & 24.71 & 24.52 & 18.856 & 18.65 & 18.45 & 18.25 \\
\hline Crude fiber $(\%)$ & 3.83 & 4.14 & 4.46 & 4.77 & 3.45 & 3.76 & 4.07 & 4.39 \\
\hline
\end{tabular}

Control; T 5\%: batch 5\%; T 10\%: batch $10 \%$ and T $15 \%$ : batch $15 \%$.

\section{Data collection method and measured parameters}

\section{Weekly Food Consumption (WFC)}

It is expressed in grams per day per subject and is obtained from the following formula:

$$
\mathrm{WFC}=\frac{\mathrm{TFC}(\mathrm{g})}{\text { Total number of birds }}
$$

\section{TFC: Total Food Consumption per week}

The live weight of the quail (LW), expressed in grams per bird.

$$
\mathrm{LW}=\frac{\text { Sum of live weight of quails }(\mathrm{g})}{\text { Number of quails }}
$$

Average Weekly Gain (AWG), expressed in grams per week per subject

AWG $(\mathrm{g})=$ Average weight of nw $(\mathrm{g})-$ Average weight of $1 \mathrm{w}(\mathrm{g})$

$\mathrm{nw}=$ new week and $\mathrm{lw}=$ last week

\section{Consumption Index (CI)}

Consumption Index $(\mathrm{CI})$ is the ratio that measures the amount of feed consumed to produce one $\mathrm{kg}$ of egg or meat in poultry.

$\mathrm{IC}=\frac{\mathrm{WFC}(\mathrm{g})}{\mathrm{AWG}(\mathrm{g})}$

Feed cost of Japanese quail in F CFA per $\mathrm{kg}$ of weight gain (FC) 
Price per kilogram of feed (FCFA) x WFC (g)

$\mathrm{FC}=\frac{\mathrm{AWG}(\mathrm{g})}{\mathrm{AWrit}}$

FC: feed cost of Japanese quail expressed in F CFA/kg of weight gain.

TFC: Total food consumption expressed in grams per week per subject.

AWG: Average Weekly Gain, expressed in grams per week per subject.

\section{Statistical analysis of data}

Data were entered using Excel 2013 spreadsheet software. Statistical analyses were performed by Graph Pad Prism 8.0.0 software and results were presented in graphical or tabular form and were expressed as mean \pm Standard Error of the Mean (SEM) of three samples of $P$ biglobosa pulp and three replicates for the zootechnical parameters of the quail individuals considered. Differences were considered significant at the $5 \%$ level.

\section{RESULTS AND DISCUSSION}

The analysis of the P. biglobosa pulp used in this study showed that for $100 \mathrm{~g} \mathrm{~ms}, 359.072 \mathrm{Kcal}$ of energy; $5.04 \mathrm{~g}$ of protein and $9.81 \mathrm{~g}$ of fiber with a mineral and vitamin complex concentrate (Table 2). The comparative bromatological profile of corn flour and P. biglobosa pulp revealed that corn flour is richer in energy, protein and less fibrous than $P$. biglobosa pulp. In terms of minerals and vitamins, $P$. biglobosa pulp is much richer than corn flour (Table 3).

Table 2. Nutritional composition of Parkia biglobosa pulp in $100 \mathrm{~g}$ of dry matter (ms).

\begin{tabular}{ll}
\hline \multicolumn{1}{c}{ Elements analyzed } & Values \\
\hline Energy (kcal/100 g of dry matter) & $359.10 \pm 6.33$ \\
Moisture content (\% of dry matter) & $15.38 \pm 0.67$ \\
Protein (g/100 g of dry matter) & $5.04 \pm 0.05$ \\
Carbohydrates (g/100 g of dry matter) & $82.52 \pm 0.53$ \\
Fat (g/100 g of dry matter) & $0.91 \pm 0.01$ \\
Ash (g/100 g of dry matter) & $4.17 \pm 0.01$ \\
Fiber $(\mathrm{g} / 100$ g of dry matter) & $9.81 \pm 0.03$ \\
Ca (mg/100 g of dry matter) & $171.50 \pm 5.35$ \\
Iron (mg/100 g of dry matter) & $8.04 \pm 1.05$ \\
Mg (mg/100 g of dry matter) & $90.06 \pm 2.02$ \\
P (mg/100 g of dry matter) & $131.30 \pm 6.28$ \\
Zn (mg/100 g of dry matter) & $5.56 \pm 0.05$ \\
K (mg/100 g of dry matter) & $1571.70 \pm 20.07$ \\
Vitamin C (mg/100 g of dry matter) & $70.25 \pm 2.44$ \\
\hline
\end{tabular}

Values were expressed as mean $\pm \operatorname{ESM}(n=3)$.

Table 3. Comparative bromatological profile of corn and Parkia biglobosa pulp.

\begin{tabular}{lcc}
\hline Elements analyzed & Parkia biglobosa pulp & White corn flour (FAO, 2012) \\
\hline Moisture content (\% of dry matter) & $15.38 \pm 0.67$ & 11.5 \\
Energy (kcal/100 g of dry matter) & $3.59 \pm 6.33$ & 351 \\
Carbohydrates (g/100 g of dry matter) & $82.52 \pm 0.53$ & 64.5 \\
Fats (g/100 g of dry matter) & $0.91 \pm 0.01$ & 4.0 \\
Protein (g/100 g of dry matter) & $5.4 \pm 0.05$ & 9.7 \\
Fibers (g/100 g of dry matter) & $9.81 \pm 0.03$ & 9.0 \\
Ash (g/100 g of dry matter) & $4.17 \pm 0.01$ & 1.4 \\
P (mg/100 g of dry matter) & $131.30 \pm 6.28$ & 198 \\
Ca (mg/100 g of dry matter) & $171.5 \pm 5.35$ & 18 \\
K (mg/100 g of dry matter) & $1571.70 \pm 20.07$ & 315 \\
Mg (mg/100 g of dry matter) & $90.06 \pm 2.02$ & 93 \\
Zn (mg/100 g of dry matter) & $5.56 \pm 0.05$ & 1.73 \\
Iron (mg/100 g of dry matter) & $8.04 \pm 1.05$ & 3.8 \\
Vitamin C (mg/100 g of dry matter) & $70.25 \pm 2.44$ & Traces \\
\hline
\end{tabular}

Values were expressed as mean $\pm \operatorname{ESM}(n=3)$. 


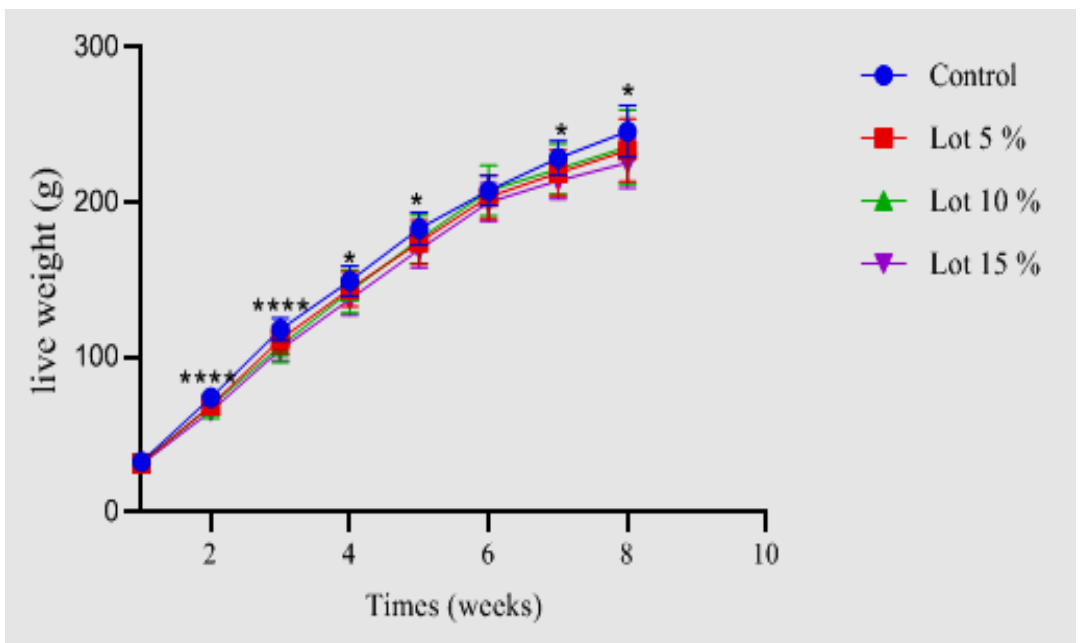

Figure 1. Evolution of the live weight Evolution of the birds following the time.

Control: feed without $P$ biglobosa pulp (T 0\%); Batch 5\%: feed with 5\% P. biglobosa pulp (T 5\%); Batch 10\%: feed with $10 \%$ P. biglobosa pulp (T 10\%) and Batch 15\%: feed with 15\% P. biglobosa pulp (T 15\%). Values are presented as mean \pm SEM (n $=3$ ). Significantly different between all batches, $*$ : $\mathrm{p}<0.05 ; * * *: \mathrm{p}<0.0001$.

Table 4. Average weekly gain of birds according to rearing phase.

\begin{tabular}{lccccc}
\hline \multicolumn{1}{c}{ Breeding phases } & Control & T 5\% & T 10\% & T 15\% & p value \\
\hline Start-up & $36.96 \pm 0,73^{\mathrm{a}}$ & $34.8 \pm 0,23^{\mathrm{b}}$ & $33.34 \pm 0.74^{\mathrm{bc}}$ & $32.15 \pm 1,27^{\mathrm{c}}$ & $0.0001(* * * *)$ \\
Growth & $25.53 \pm 0,65^{\mathrm{a}}$ & $24.4 \pm 0,34^{\mathrm{a}}$ & $25.72 \pm 0.75^{\mathrm{a}}$ & $24.12 \pm 0,75^{\mathrm{a}}$ & 0.0511 \\
\hline
\end{tabular}

Control: feed without P. biglobosa pulp (T 0\%); Batch 5\%: feed with 5\% P. biglobosa pulp (T 5\%); Batch 10\%: feed with $10 \%$ P. biglobosa pulp (T 10\%) and Batch 15\%: feed with 15\% P. biglobosa pulp (T 15\%). Values are presented as mean \pm SEM $(n=3)$. Values with the same letter on the same line are not significantly different at the 5\% level. Significantly different between all batches: $* * * *: \mathrm{p}<0.0001$.

Table 5. Food consumption of quails according to the rearing phase.

\begin{tabular}{lccccc}
\hline \multicolumn{1}{c}{ Breeding phases } & Control & T 5\% & T 10\% & T 15\% & p value \\
\hline Star-up & $60.17 \pm 1.08^{\mathrm{c}}$ & $64.66 \pm 1.55^{\mathrm{ab}}$ & $67.22 \pm 2.66^{\mathrm{a}}$ & $68.62 \pm 0.89^{\mathrm{a}}$ & $0.0001(* * * *)$ \\
Growth & $131.1 \pm 0.49^{\mathrm{c}}$ & $133.6 \pm 0.74^{\mathrm{bc}}$ & $136.2 \pm 0.38^{\mathrm{b}}$ & $140.7 \pm 0.58^{\mathrm{a}}$ & $0.0011(* * *)$ \\
\hline
\end{tabular}

Control : feed without P. biglobosa pulp (T 0\%) ; Batch 5\%: feed with 5\% P. biglobosa pulp (T 5\%) ; Batch 10\%: feed with $10 \%$ P. biglobosa pulp (T 10\%) and Batch 15\%: feed with 15\% P. biglobosa pulp (T 15\%). Values are presented as mean \pm SEM of three repetitions $(n=3)$. Values with the same letter on the same line are not significantly different at the 5 $\%$ level. Significantly different between all batches: $* * * \mathrm{p}<0.001 ; * * * * \mathrm{p}<0.0001$

Table 6. Food consumption index according to rearing phase.

\begin{tabular}{lccccc}
\hline \multicolumn{1}{c}{ Breeding phases } & Control & Lot 5\% & Lot 10\% & Lot 15\% & p value \\
\hline Start-up & $1.53 \pm 0.03^{\mathrm{a}}$ & $1.68 \pm 0.05^{\mathrm{a}}$ & $1.77 \pm 0.07^{\mathrm{a}}$ & $1.87 \pm 0.51^{\mathrm{a}}$ & 0.0501 \\
Growth & $5.62 \pm 0.16^{\mathrm{a}}$ & $6.36 \pm 0.17^{\mathrm{b}}$ & $6.05 \pm 0.45^{\mathrm{b}}$ & $7.41 \pm 0.76^{\mathrm{c}}$ & $0.0001(* * * *)$ \\
\hline
\end{tabular}

Control: feed without P. biglobosa pulp (T 0\%); Batch 5\%: feed with 5\% P. biglobosa pulp (T 5\%) ; Batch 10\%: feed with $10 \%$ P. biglobosa pulp (T 10\%) and Batch 15\%: feed with 15\% P. biglobosa pulp (T 15\%). Values are presented as mean \pm SEM of three repetitions $(n=3)$. Values with the same letter on the same line are not significantly different at the $5 \%$ level. Significantly different between all batches: $* * * * p<0.0001$. 
The average hatching weight of quail in our study was $7 \pm$ $0.02 \mathrm{~g}$. At the eighth week, the average weight of quails was $245.8 \pm 16.79 \mathrm{~g} ; 233.7 \pm 20.3 \mathrm{~g} ; 235.9 \pm 23.74 \mathrm{~g}$ and $225.7 \pm 16.26 \mathrm{~g}$ respectively for the control and treated batches in the order of increasing substitution rate of maize for P. biglobosa pulp. The results showed that from 0 to 4 weeks of age, growth was similar for all treated lots compared to the control batch (Figure 1). After this age, weight growth was better for quails fed with the ration containing $10 \%$ P. biglobosa pulp and those of the control lot compared to quails fed with the rations of $5 \%$ and $15 \%$ $P$. biglobosa pulp respectively. This observation was very remarkable in the sixth week of age of Japanese quails.

The evolution of the cumulative weekly average gain during the two phases of quail rearing was represented in table 3. The statistical analysis showed that in the start-up phase, the control lot gained more weight followed by the $5 \%$ and $10 \%$ batches $(\mathrm{p}<0.0001)$. On one hand, the average weekly gain cumulative in the growth phase showed no significant difference between the control and treated batches. On the other hand, the incorporation of $15 \%$ P. biglobosa pulp altered the weight growth of the quails without the weekly average gains of the four rations being significantly different $(\mathrm{p}>0.05)$.

The average food consumption of the control and $15 \%$ batches was respectively, $60.17 \mathrm{~g}$ and $68.62 \mathrm{~g}$ at start-up and $131.1 \mathrm{~g}$ and $140.7 \mathrm{~g}$ at growth. Indeed, the $15 \%$ batch consumed more feed than the $10 \%$ and $5 \%$ batches (Table 4). Statistical analysis showed that this consumption increased with age but remained different between the different treatment batches. The feed conversion ratio of the control and $15 \%$ batches was 1.53 and 1.87 at start-up and 5.62 and 7.41 at growth, respectively. Indeed, the $15 \%$ lot recorded a higher consumption index compared to the $10 \%$ and 5\% treated batches (Table 5). Statistical analysis shows that there was no significant difference in feed conversion between the four batches in the starting phase. However, in the growth phase, there was a significant difference $(p<0.0001)$ between the four batches. The $15 \%$ lot was the lot that converted the least feed during both rearing phases compared to the other batches. The use of $P$. biglobosa pulp reduced the price of feed for quails from 2.75 to $8.25 \mathrm{FCFA} / \mathrm{kg}$ in the start-up phase and from 2.55 to $8.05 \mathrm{FCFA} / \mathrm{kg}$ compared to the control ration. The feeding cost in quails fed with the $P$. biglobosa pulp-based feed rations showed no significant difference $(\mathrm{p}>0.05)$ between the treated batches compared to the control batch during the two rearing phases of the Japanese quail. Indeed, compared to the control ration, the rations based on $5 \%$, $10 \%$ and $15 \%$ of $P$. biglobosa pulp resulted in an increasing in feed cost from $13.20 \%$ to $27.06 \%$ in the startup phase and $0.79 \%$ to $9.64 \%$ in the growth phase respectively. From an economic point of view, the three incorporation rates of $P$. biglobosa pulp did not reduce the feed cost compared to the control.

Table 7. Feed prices and feed costs for Japanese quail fed with cowpea pulp rations.

\begin{tabular}{|c|c|c|c|c|c|c|}
\hline & Breeding phases & Control & T $5 \%$ & $\mathrm{~T} 10 \%$ & Т $15 \%$ & $\mathrm{p}$ value \\
\hline \multirow[t]{2}{*}{ Price of feed (FCFA/kg of feed) } & Start-up & 268,25 & 265,5 & 262,75 & 260 & \\
\hline & Growth & 234,6 & 231,85 & 229,1 & 226,35 & \\
\hline \multirow[t]{3}{*}{ Feed cost (F CFA/kg of weight gain) } & Start-up & $436^{\mathrm{a}}$ & $493^{\mathrm{a}}$ & $529^{a}$ & $554^{\mathrm{a}}$ & 0,050 \\
\hline & Growth & $1203^{\mathrm{a}}$ & $1269^{\mathrm{a}}$ & $1213^{\mathrm{a}}$ & $1320^{\mathrm{a}}$ & 0,050 \\
\hline & Global & $819,5^{\mathrm{a}}$ & $881^{\mathrm{a}}$ & $871^{\mathrm{a}}$ & $937^{\mathrm{a}}$ & 0,050 \\
\hline
\end{tabular}

Control: feed without P. biglobosa pulp (T 0\%); Batch 5\%: feed with 5\% P. biglobosa pulp (T 5\%); Batch 10\%: feed with $10 \%$ P. biglobosa pulp (T 10\%) and Batch 15\%: feed with 15\% P. biglobosa pulp (T 15\%). Values are presented as mean \pm SEM (n $=3$ ). Significantly different between all batches, $*: \mathrm{p}<0.05$.

The bromatological profile which was obtained showed that the P. biglobosa pulp meets the criteria of choice of a food ingredient by its energy, protein and mineral and vitamin complex. This confirms previous work in this area by other authors such as (Ouedraogo, 1987) and (Gernah et al., 2007), on the fact that $P$. biglobosa pulp is a very nutritious flour. From 0 to 4 weeks of age, the growth was similar for all treated lots compared to the control batch (Figure 1). After this age, weight growth was better for quails fed with the ration containing $10 \%$ P. biglobosa pulp and those of the control lot compared to quails fed with the rations of $5 \%$ and $15 \%$ P. biglobosa pulp respectively. This observation was very remarkable in the sixth week of age of Japanese quails. This can be explained by the fact that the birds adapted better and better to the substitution of corn by $P$. biglobosa pulp in their diet. Several authors have reported the same growth pattern in the quail Coturnix japonica (Ikaya et al., 2005; Kizilkaya et al., 2006; Vatsalya \& Arora, 2012). The average weekly gain evolved in a decreasing way with the age of the birds. It was very high during the first three weeks of age of the birds, which corresponded to the start-up phase of the Japanese quail. This difference in weight gain observed between birds of all batches during the start-up phase, explained why the growth rate of birds in the control batch was higher than that of the treated batches during the first three weeks of rearing. However, this weight gain was small during the growth phase of the birds and showed no significant difference between batches during this phase of quail development. This explained the fact that the 
incorporation of $15 \%$ P. biglobosa pulp altered the weight growth of the quails without the weekly average gains of the four rations being significantly different in the growth phase.

In the light of these results, we can say that the fattening performance of Japanese quail (Coturnix japonica) is noticeable in the first three weeks of rearing. Some authors like (Aryeetey, 2011; Sezer \& Tarhan, 2005) also reported this fast fattening performance of this Japanese quail. Some authors like (Sezer \& Tarhan, 2005) also reported this rapid fattening performance of quail. The feed consumption of the quails increased with age and the increasing level of substitution of corn by $P$. biglobosa pulp. This is explained by the fact that the increasing level of substitution with $P$. biglobosa pulp led to a decrease in the energy level of the feed ration of the 5\%,10\% and $15 \%$ batches. Indeed, according to (Swennen et al., 2007), good performance of poultry in breeding depends on the characteristics of the feed such as composition, feed intake, digestion and absorption processes.

The decrease in the energy level of the quail ration in the treated lots resulted in a slight increase in food consumption compared to the control batch. (Baransaka, 1998)obtained a mean feed intake that increased ( $<<0.05)$ with increasing levels of $P$. biglobosa pulp in laying hens in the pullet phase. This confirmed the energy imbalance between the two ingredients (corn and cowpea pulp). Our results corroborate with the results reported by some authors such as (Berrama et al., 2011; Djouvinov \& Mihailov, 2005). Bromatological analysis of P. biglobosa pulp has shown that beyond its nutritional qualities, it is very rich in dietary fiber. Ouedraogo, (1987) and (Gernah et al., 2007) reported a crude dietary fiber content of 11 and $19 \%$ respectively, much higher than in our study. The increment in feed consumption of quail with the increasing level of substitution of corn by pulp has resulted in an increasing intake of dietary fiber. This explained the low feed conversion and growth rate of the quails in the $15 \%$ treated batch compared to the other two treated batches and the control. Moreover, due to their less developed digestive system in microflora, the poultry do not have the capacity to better valorize these fibers, as an additional source of energy. Dietary fiber is much feared to have adverse effects on growth performance of birds especially monogastrics due to its low digestibility (Musamba et al., 2011). The fiber levels in our different formulated feeds increased with the increasing level of substitution of P. biglobosa pulp. The $15 \%$ batch feed had the highest fiber level compared to the other two treated batches. Recommended fiber levels of 3 to $3.88 \%$ in the quail feed. The availability of $P$. biglobosa pulp at low cost in some localities of our country and its good nutritional value made it possible to reduce the food, the rate of corn between $3.5 \%$ to $20.28 \%$ and $3.72 \%$ to $15.92 \%$ respectively for the phases of starting and growth of the Japanese quail. This resulted in a reduction in the price per kilogram of feed of the $5 \%, 10 \%$ and $15 \%$ lot rations compared to the control lot. The $5 \%$ to $15 \%$ batches rations which in combination with the similarity in average weekly gain (AWG) did not result in a significant decrease in feed cost per $\mathrm{kg}$ live weight of Japanese quail. The feed costs obtained with the 5\%, 10\%, and $15 \%$ rations compared to the control lot showed that there was no reduction in feed cost. (Houndonougbo et al., 2012) reported a decrease in price per kilogram of feed and feed cost per kilogram of weight gain with the incorporation of dried cassava leaves in the diet of laying hens in the chick and pullet phases. Our results could be explained by the fact that our food rations were not isoenergetic and iso-proteinic, which led to the increasing in food consumption and its low valorization by the birds because of the dietary fibers. We also obtained a low weight gain of the birds in the start-up phase but which improved for the batches treated in the growth phase. So we can say that the $P$. biglobosa pulp was better valued in the growth phase of the Japanese quail.

\section{CONCLUSION}

In this study considered as preliminary, the substitution of corn by cowpea pulp was a presumptive test in order to conduct further studies on the valorization of this nutritious meal in Japanese quail feeding. The possibilities for improvement in energy balance are very important as the two raw materials differ both in quantity and quality. This pulp can, in fact according to the data of the present study, substitute corn at rates of 5 to $15 \%$ in the feed of the quail while maintaining its growth performance. The results show that cowpea pulp has an interesting nutritional value and its concentration in vitamins and minerals could contribute to stimulate the immune system in quail without affecting the growth performance. Faced with the high cost of cereals and the uncertainty of their sustainable supply as a source of energy, a maize-pulp associated would help poultry farmers not only to reduce the cost of food, but also to promote coturniculture, as an income-generating activity to vulnerable social classes.

\section{ACKNOWLEDGEMENTS}

The authors thank the Direction of the Higher School of Agronomy and the International Atomic Energy Agency (IAEA) for the equipment of the Research Laboratory on Agroresources and Environmental Health of the University of Lomé (LARASE-UL) which allowed the analysis of Parkia biglobosa pulp. They also thank the Rehoboth Poultry Farm located in Vogan (chief town of the Vô prefecture), in the Maritime region of Togo, which served as an experimental site.

\section{REFERENCES}

Agiang, E., Ayuk, A., Nwelle, J., \& Uzegbu, H. (2004). Performance of broiler fed diets with graded levels of cassava waste meal (CWM) as energy source. Journal of Agriculture and Food Sciences, 2(1), 13-19.

Aryeetey, E. (2011). This Report satisfies a statutory requirement of the Vice-Chancellor to document annually the work of the University for Congregation. 
The report covers the 2009/10 academic year. I am pleased to note that in spite of heavy teaching and administrative loads, staff continue to apply themselves to conducting research and giving presentations at conferences and workshops culminating in various kinds of publications. 792 publications, 1158 research projects and 835 .

Baransaka, N. (1998). Etudes de l'aviculture moderne dans la zone de Bobo-Dioulasso et de l'utilisation de la pulpe de néré dans l'alimentation des poules de races. Mémoire du diplôme d'Ingénieur du Développement Rural, IDR/UPB.

Berrama, Z., Mefti, H., Kaidi, R., \& Souames, S. (2011). Caractérisation zootechnique et paramètres génétiques des performances de croissance de la caille japonaise Coturnix japonica élevée en Algérie. Complément, 905(1), 1 .

Djouvinov, D., \& Mihailov, R. (2005). Effect of low protein level on performance of growing and laying Japanese quails (Coturnix coturnix japonica). Bulgarian Journal of Veterinary Medicine, 8(2), 91-98.

Durunna, C., Udebibie, A., \& Anyanwu, G. (2000). Combination of maize/sorghum and cassava tuber meal as a substitute for maize in diet of laying hens. Paper presented at the Proceedings of the 25th Annual Conference of the Nigeria Society of Animal Production Umudike.

Gernah, D., Atolagbe, M., \& Echegwo, C. (2007). Nutritional composition of the African locust bean (Parkia biglobosa) fruit pulp. Nigerian Food Journal, 25(1), 190-196.

Haruna, E., Musa, U., Lombin, L., Tat, P., Shamaki, P., Okewole, P., \& Molokwu, J. (1997). Introduction of quail production in Nigeria. Nigerian Veterinary Journal, 18, 104-107.

Houndonougbo, M. F.,Chrysostome, C., \& Houndonougbo, V. (2012). Performances bioéconomiques des poulettes alimentées avec des rations à base de feuilles séchées de manioc (Manihot esculenta). International Journal of Biological and Chemical Sciences, 6(2), 670-676.

Ikaya, K., Balci'oglu, M., Yolcu, H., \& Karabag, K. (2005). The application of exponential method in the analysis of growth curve for Japanese quail. Archiv Fur Geflugelkunde, 69(5), 193-198.
Kizilkaya, K., Balcioglu, M., Yolcu, H., Karabag, K., \& Genc, I. (2006). Growth curve analysis using nonlinear mixed model in divergently selected Japanese quails. Archiv Fur Geflugelkunde, 70(4), 181-186.

MAEP. (2008). Stratégie de la relance de la production agricole au Togo. 72p.

Musamba, E. B., Ngaga, Y. M., Boon, E. K., \& Giliba, R. A. (2011). Impact of socio-economic activities around Lake Victoria: land use and land use changes in Musoma Municipality, Tanzania. Journal of Human Ecology, 35(3), 143-154.

Odo, B. I., \& Nnadi, A. (2013). Growth response of quails (Coturnix coturnix japonica) to varying levels of cassava tuber meal (Manihot esculenta) as replacement for maize (Zea mays). Revista Científica UDO Agrícola, 13(1), 146-149.

Ouedraogo, M. (1987). Contribution à l'étude de la valeur nutritive de la poudre jaune du Néré et du soumbala. Recueil des communications présentées au séminaire national sur les essences forestières locales, tenu à Ouagadougou du, 6, 204-210.

Sezer, M., \& Tarhan, S. (2005). Model parameters of growth curves of three meat-type lines of Japanese quail. Czech Journal of Animal Science, 50(1), 22-30.

Shamna, T., Peethambaran, P., Jalaludeen, A., Leo, J., \& Muhammad, A. (2013). Broiler characteristics of Japanese quails (Coturnix coturnix japonica) at different levels of diet substitution with Azolla pinnata. Animal Science Reporter, 7(2).

Swennen, Q., Decuypere, E., \& Buyse, J. (2007). Implications of dietary macronutrients for growth and metabolism in broiler chickens. World's Poultry Science Journal, 63(4), 541-556.

Ukashatu, S., Bello, A., Umaru, M., Onu, J., Shehu, A., Mahmuda, A., \& Saidu, B. (2014). A study of some serum biochemical values of Japanese quails (Coturnix Coturnix Japonica) fed graded levels of energy diets in Northwestern Nigeria. Scientific Journal of Microbiology, 3(1), 9-13.

Vatsalya, V., \& Arora, K. L. (2012). Allometric growth of testes in relation to age, body weight and selected blood parameters in male Japanese quail (Coturnix japonica). International Journal of Poultry Science, 11(4), 251. 